\title{
Stanisław Moniuszko: The Works in Context of Russian Contacts - 15 Songs to Words by Russian Poets
}

\author{
Olga Sobakina ${ }^{1, *}$ \\ ${ }^{1}$ Department of Music Theory, State Institute for Art Studies, Moscow, Russia \\ *Corresponding author.E-mail: olas2005@mail.ru
}

\begin{abstract}
The works by Moniuszko always found warm response in Russia; Dargomyzhsky, Glinka, Cui, Serov contributed to the promotion of him. Moniuszko's visits to St. Petersburg took place in 1842, 1849, 1856 and 1870. Not getting a job in St. Petersburg, Moniuszko, however, managed to get permission from the censorship to publish his romances. But only in 1857, 22 romances in two issues (albums) were published by Northern Lyre. Most of them are romances written earlier on poems by Polish poets translated by Benediktov. The first album of Moniuszko's 10 romances in Polish published in Russia included Those Evening Bells to the words by Kozlov. For the second album, Moniuszko chose 12 romances based on poems by Polish poets, translated by Benediktov. One more issue "Six Romances" was published by Bernard's publishing house in 1870 with Russian texts. In 1868 Bernard published 13 of new Moniuszko's romances in one collection "Romances and Songs - Music by S. Moniuszko". 12 of them were composed to words by Russian poets. Two other "Russian" romances were introduced later. In these pieces, the composer appears as a master not only of romantic vocal lyrics, developing the traditions of Schubert and Schumann, but also as a rather unexpected adherent of the Russian salon romance, which expresses deeply felt human emotions in a simple and sincere musical language.
\end{abstract}

Keywords: Stanistaw Moniuszko, “Russian” romance, Northern Lyre, Dargomyzhsky, Cui, Bernard.

\section{INTRODUCTION}

In the Polish musical culture of the 19th century, the works by Stanisław Moniuszko (1819-1872) are comparable in value only with those by Frederic Chopin. 'I am not creating anything new! Wandering around the Polish lands, I am filled with the spirit of folk songs. Of these, irrespective of my intentions, inspiration spills over into all my works' - this is how the composer wrote about himself in his late years [1]. Moniuszko's life path is connected with the history of three contemporary states, Poland, Lithuania and Belarus, but he was also interested in expanding his creative activities to Russia.

\section{MONIUSZKO'S VISITS TO ST. PETERSBURG}

In 1836 Stanisław Moniuszko arrived to Vilna (now Vilnius), where his engagement to Alexandra
Müller took place, which determined his future fate. The bride's mother made it a condition of her consent to the marriage to receive any special education, since Stanisław due to illness could not graduate from the gymnasium and enter the civil service. The Moniuszko family made a choice for a musical education and in 1837 sent their son to study in Berlin, this city was famous for the solid status of its institutions. In Berlin, Moniuszko was attracted by music related with word - song, cantata, opera; his first vocal opuses belong to these years. Moniuszko's first works published in 1838 by the Berlin publishing house Bote und Bock were Three Songs to words by Mickiewicz, as well as the ballad Three Budrys (1840). These works brought Moniuszko the first recognition of his talent, and in August 1840 the long-awaited wedding took place in Vilna. Moniuszko's father did not manage well, the family's fortune declined and therefore gradually the young couple decided to gain a position in the musical world of the Russian capital. 
In the autumn of 1842, Moniuszko came to St. Petersburg for the first time: before settling in Vilna for eighteen years, the composer attempted to find a work worthy of his talent in the capital of the Russian Empire. Aware of the advantages of life in the capital, Moniuszko wrote to his wife: 'I have to work somewhere, if not for the sake of money, then for the status, but where is it more likely to achieve it, if not in St. Petersburg?' [2]. Hoping for the support of Prince Lvov, director of the Court Singing Chapel, Moniuszko made a fatal mistake: Lvov himself worked in the theatre, wrote the music, and could not afford to have a rival in the person of Moniuszko. The composer himself notes this. He writes in a letter to his wife: 'Lvov is the director of the choristers, and at the same time also writes the music for them - he will not allow someone who came from Vilna to interfere in his household' [3].

Not getting a job in St. Petersburg, Moniuszko, however, managed to get permission from the censorship to publish his romances. In the Petersburg Weekly, which was published in Polish, Moniuszko writes about the idea of their publication as follows: 'If beautiful poetry, combined with music, is able to open its way to an ear and a heart that is almost non-musical, then even weaker music, which is less successful but with excellent poetry, will find indulgence; and what is national, local, what is the echo of our childhood memories, will never cease to be liked by the inhabitants who were born and raised on this earth' [4].

In the same 1842, Moniuszko received the modest position of organist in the church of St. Jan in Vilna and staged his first operettas at the Schmitthoff Theater in Minsk. At the same time, the idea arose to release the first Home Songbook, which was published in April 1844. Alexander Walicki in his first monograph about Moniuszko (1873) writes: 'It is difficult to understand the impression that the appearance of the first songs of Moniuszko made on everyone. Before that, we had a few Russian compositions for singing. There were very few people singing from notes in Lithuania (...) and the Polish vocal repertoire did not exist at all' [5]. Four issues of the Home Songbook belong to the Vilna period. Among them there are a variety of vocal forms - from genre pictures to ballads. All researchers of the composer's work emphasize that the very first songs marked a new stage in the development of Polish vocal music and were distinguished by genuine national intonations and originality. Twelve notebooks, six of which were published during Moniuszko's lifetime, included 260 songs. Both in Poland and in Russia, critics highly appreciated the importance of these works, but their distribution in Poland was very slow, since the society was not ready to receive serious music. During these years, the creative life of Vilna came to a standstill, and one of the former centers of Polish romanticism turned into a cultural province. The opera was reopened only in 1845 in the city hall, and the Vilna orchestra, according to Moniuszko, was indecent. Moniuszko was young and full of strength, but life did not give him opportunities for success, but offered hard work and struggle with difficulties. He spent eighteen years in Vilna, not leaving him because of the need to earn money and occasionally leaving only to Warsaw and St. Petersburg. Recognition for his work came slowly.

Moniuszko's second visit to St. Petersburg took place in 1849. Composer stayed there for several months, introducing his numerous compositions to the capital's music lovers. Moniuszko's concerts were advertised by the popular Russian writer Fadey Bulgarin in the newspaper The Nothern Bee (Severnaya Pchela). The journalist wrote: 'Our public, perhaps, for the first time hears the name of Mr. Moniuszko. He is a music lover and a firstclass composer, very famous in the western provinces and in the Kingdom of Poland. His "home songs" ... to the best poems of Polish poets, are found in all educated families' [6]. The cantata Milda made a huge impression on the audience. Some later, Bulgarin wrote about it in the Kurier Wileński: 'All the seats in the hall were occupied, and everyone was delighted with excellent music. What pleased us most was that the gifted Russian composers and amateur virtuosos gave full justice to Mr. Moniuszko, extolled his music and accepted him with traditional Russian hospitality' [7]. Alexander Walicki wrote: 'After the performance of Milda, Moniuszko's fame was established in St. Petersburg. The entire artistic world, even the aristocratic one, tried to get to know him personally by visiting his modest apartment in the basement on Millionnaya Street' [8].

Mention that the works by Moniuszko always found warm response in Russia; Glinka, Dargomyzhsky, Cui, Serov contributed to the promotion of his works. Moniuszko became especially close to Dargomyzhsky, to whom he dedicated his Tale overture in April 1849 (Moniuszko's manuscript, donated to the Russian composer, is kept in St. Petersburg). At the musical evenings at Dargomyzhsky's salon, which attracted 
many participants, Moniuszko's compositions were often sounded. It is also interesting that Cui studied with Moniuszko in Vilna and wrote his first vocal works under his guidance - about 50 romances to the words by Polish and French poets. Subsequently, Cui wrote a lot about Moniuszko. In an article in memory of the teacher, he called him 'a Slavic composer, not so much a Pole as a Lithuanian, since in his music, as well as in his character, there was no Polish liveliness, gaiety, sensitivity' [9]. This is a very important observation that allows one to more accurately characterize the style and melodic thinking of Moniuszko. Let us clarify that the Litvins is an ethnonym in some Slavic languages that was applied to various peoples - Lithuanians, Slavs of the Grand Duchy of Lithuania as a whole, Belarusians - up to the 20th century. Initially associated with the self-name of the Baltic ethno-tribal group, Lithuania, with the emergence of the Grand Duchy of Lithuania (12401791), spread to the inhabitants of the principality (as well as to the Western Russian written language, which was the state language). In addition to Moniuszko, famous Polish artists Michał Kleofas Ogiński, Tadeusz Kościuszko, Adam Mickewicz were Litvins. Their works is closely related to the history and culture of modern Belarus and Lithuania.

So, in 1856 the St. Petersburg audiences were well prepared to Moniuszko's third visit. The cantatas Milda and Niola (Undine), overtures The Tale and Cain were performed. Moniuszko himself conducted, and the soloists were such prominent Russian singers of that time as Anisya Bulakhova and Osip Petrov (the first performer of the parts of Susanin and Ruslan). The texts of both cantatas were translated by the then-famous Russian poet Vladimir Benediktov. This time, the concert, which was facilitated by the court singer and chambermaid of honor Praskovya Barteneva, took place in the palace of Prince Yusupov. We can judge about the success of this visit due to two articles by Alexander Serov, as well as to a review by Józef Przecławski in the St Petersburg Weekly. The latter author noted 'the poetic nature of the composer's soul' and 'his accuracy in the choice of expressive devices, testifying to his delicate taste. Nothing was either too much or too little. He interpreted the public not as a crowd of onlookers, which at first had to be stunned, in order to delight afterwards, but as a poetic community sympathetic to the poetry of his soul' [10]. 'I do not hesitate to put them along with the best that is in music', this is how Serov characterized Moniuszko's romances, underlining such qualities as 'grace and nobility of the melody, charm and intelligence of development, absence of any sophistication, any exaggeration'. It is worth noting that Serov mentioned texts in Polish as an obstacle to the distribution of Moniuszko's vocal music. The critic supposed that translating Polish romances into Russian would not be enough, since translation will never replace the value of the original text: "the finer, more delicate the intention of the composer, the more unsatisfactory is the translation', writes Serov [11].

\section{MONIUSZKO'S "RUSSIAN" ROMANCES}

It is not known whether Moniuszko accepted the advice of the famous St. Petersburg composer and critic, but in 1857 an important event took place: 22 romances in two issues (albums) were published by Bittner's publishing house Northern Lyre. Most of them are romances written earlier on poems by Polish poets translated by Benediktov. Besides, this first album of Moniuszko's 10 romances in Polish published in Russia included Those Evening Bells to words by Ivan Kozlov (1852, from Thomas Moore). For the second album, published in the same way as the first in 1857 , Moniuszko chose 12 romances based on poems by Polish poets, translated by Benediktov. There were no romances to Russian poems in this album. In 1869, the first Russian performance of Halka took place at the Bolshoy Theatre in Moscow; in 1870, the opera was successfully staged in St. Petersburg in the presence of the composer. It was Moniuszko's the fourth and the last visit to the capital. In anticipation of it, in 1868 Bernard published 13 of new Moniuszko's romances in one collection "Romances and Songs - Music by S. Moniuszko". 12 of them were composed to words by Russian poets, whose names, with a few exceptions, are unknown; subsequently, at different times, these "Russian" romances were published in Polish translations (and in Russia they were also reprinted by Jurgenson in 1897 among the other romances by Moniuszko). As the $13^{\text {th }}$ romance, one more Serenade in translation from Polish into Russian was also included, that seems now the paradoxes.

As regards Moniuszko's "Russian" romances, it is worth noting that in Moniuszko's lifetime, in 1870 , the collection "Six Romances" were issued by Bernard's publishing house; all of them were earlier pieces to Polish texts translated by Benediktov, this album includes the now famous 
songs Barcarolle, Kazak and the others with Russian texts. Subsequent reprints of "Russian" romances led to some confusion; in particular, both The Moniuszko Almanac (1952) and The Catalogue of Moniuszko's Songs published by Erwin Nowaczyk (1954) contain no information on The Bal on Ice to the poem by Nestor Kukolnik. However, one of the title pages of a reprint of 12 "Russian" romances in Bernard's publishing house shows just this as the last number! And therefore, it was we who noticed that it was not published for the first time in the reissue of some composer's romances, carried out by Igor Belza. The autograph of this romance is now stored in the archives of the Russian National Museum of Music in Moscow.

Moniuszko's "Russian" romances became a successful preparation for the composer's last visit to Russia. The exact dates of the composition of these romances, with a few exceptions, are unknown. This album includes the following romances, listed below in the order of their appearance in the edition:

- Дитяти|To Child

- К соловью | To Nightingale

- Слеза|Tеar

- Цыгане|Gypsies

- «Скажите мне ..." | "Sау Me ..."

• “Люблю тебя ...”| “I Love You ...”

- Серенада («Все бы слушал весенние сказки ...») | Serenade ("I would listen to spring tales ...”)

- Пряха («Плохо топлена избушка ...»)| Spinner ("The hut is poorly heated ...")

- «Расскажи моя родная ...», | “Tell, My Darling ...", words by E. von Kruse

- Песня бобыля | Bachelor's Song, words by Ivan Nikitin

- Тоска ("Я все кого-то ожсидаю ...») | Grief ("I'm waiting for somebody ...")

- «Люблю я игривые ласки ...» | О Lovely Child ("I love playful caresses ..."), words by Vasiliy Chuyevsky

In these pieces, the composer appears as a master not only of romantic vocal lyrics, developing the traditions of Schubert and Schumann, but also as a rather unexpected adherent of the Russian salon romance, which expresses deeply felt human emotions in a simple and sincere musical language. Characterizing romances, it becomes obvious that the dominant stylistic qualities are determined by the genre chosen for the miniature. In turn, they are subordinated to their super-idea - a genre scene (couplets, a song, or a real genre scene) or a lyric romance (elegies, lullabies, serenades, barcaroles). The latter predominate, since salon romance was still mainly devoted to lyrical experiences. And so we will start with them.

The romance To Child, written for the middle voice, corresponds to the elegy genre. Emotional philosophical meditation on the theme of the ups and downs of human fate is distinguished by a whimsical rhythm and complex sixth and octave upward leaps. The accompaniment imitates the guitar texture with frequent use of the tonic organ point, against the background of which there are harmonic modulations and sliding, sometimes subtle shifts in minor-major.

Romance To Nightingale was written for a high voice in the lullaby genre. The use of the high register in a piano part traditionally simulates nightingale trills. The melody chromatics in the second stanza, as well as in the piano part in the third verse, creates the feeling of a light amorous languor of the hero guarding the sleep of his beloved.

Written for a tenor in the elegy genre, Tear is saturated with second intonations, both melodic and harmonic with the characteristic scale-like line of the melody. The expressive introduction, built on a descending theme with "crying" intonations of the accompaniment, as well as the conclusion, which is preceded by a detailed, elegiac cadence of the vocal part - all this anticipates Tchaikovsky's romance style. Moniuszko's ability to foresee and anticipate the development of this genre in Russian music, his sensitivity to the "intonational dictionary" of the following decades, are surprising.

The romance for tenor Grief is written in the genre of salon romance. This vivid miniature conveys a state of unbridled thirst for love. The offbeat melodies in the beginning of the verse, characteristic for this genre, contrast with the sharp jumps in the left hand part. The culminating third verse isolated in texture and the short syncopated conclusion in the piano part convey the state of a restless soul. Concern harmony, the composer remains true to himself both in the deviation into the tonality of the subdominant (the first and second verses) and in the use of the tonic organ point (the third verse). 
The romance for a high voice $\boldsymbol{O}$ Lovely Child was written on the words by Vasiliy Chuyevsky, a popular songwriter in the middle of the 19th century. This fact was recently established by Dmitry Grinikh, who first recorded these romances in an ensemble with the author of the article. Note that in 1846 Alexander Dubuque wrote a romance to this poem. Moniuszko, like Dubuque, uses a flexible three-beat meter, but his dance "salon" romance, written in verse form, sounds much more elegant. The feeling of tonal "weightlessness" arises due to the use of an altered subdominant in the middle of the verse.

The romance I Love You was written for a middle voice in the genre of a salon waltz, it is a declaration of love, full of gratitude and delight. A short but virtuoso passage preceding the beginning of the romance creates the effect of a sharp plunge into the world of admiration and rapture with love. The composer uses his favorite "playing" in minormajor. Two impulsive verses of the romance end with a fading piano passage.

In the Serenade, the hero confesses his love in the midst of spring evening nature. Imitating the guitar texture in the accompaniment only in general terms, the composer varies it, adding either virtuoso turns or echoes. The melody is replete with grace notes and abrupt jumps, which presents a certain difficulty for the performer. However, using the triple metre, which is typical for a serenade, Moniuszko turns it into a waltz and brings in the composition an exquisite salon charm.

Two female romances "Tell, $\boldsymbol{m y}$ dear ..." (to the words by E. (Elizaveta?) von Kruse) for mezzosoprano and "Say me..." for soprano represent the genre of lyric song, which reflects women's love experiences. The first is distinguished by a transparent choral texture and typical intonations of everyday romance, while the second is interesting for its harmony, saturated with alterations and chromatics, and tells about the desire of a young girl to find her ideal lover.

The composer very often and skillfully used such a popular form in romantic music as a genre scene and the following three romances can be attributed to them. Song for middle voice Spinner (one moor in Moniuszko's vocal works) refers to the infernal theme in the works by Moniuszko, to which romantic composers often turned. The romance is dedicated to the experience of the vision of Death on a snowy night street. The accompaniment depicts the spinning of a spindle in the hands of an old woman and is based on the characteristic virtuoso sound-visual figurations in the right-hand part of the piano. However, they also convey the howling of the wind outside the window, and the movement of the vision of Death. The dashed vocal line is devoid of jumps and is written in the octave range, conveying a state of despondency, and at the end of the fright from the vision of Death. Bachelor's Song (or Merry Song in the current Polish version), as Nowaczyk suggests, was written for a baritone in 1856, to words by Ivan Nikitin. In terms of genre, it is a Russian dance song: the repetitive tonic-dominant harmonies with characteristic tunes in the right hand of the pianist resemble the sound of a Russian harmonica, although the background created by the virtuoso scale-like passages in the left hand is far from the characteristic texture for this instrument. Romance for tenor Gypsies also impresses with its vivid genre: the verse consists of two contrasting parts - the elegiac solo in minor key and the major dance section, which expresses the unrestrained fun, exciting the heroes. This is not the only appeal by Moniuszko to the gypsy theme. Suffice it to recall his operetta Gypsies, which was written in Vilna in 1850 . The romance imitates the typical vocabulary of the czardas, based on the opposition of two sections - slow and fast (friska) with a characteristic gradual acceleration of the tempo and virtuoso tunes in the accompaniment.

So, in conclusion let turn to the very early "Russian" romance Those Evening Bells. Text by Ivan Kozlov (from Thomas Moore) was extremely popular in Russia. Moniuszko, most likely, heard Alyabyev's song and for the first Russian edition decided to write a romance based on a well-known plot. The genre of barcarole with a characteristic swaying accompaniment turned thanks to using of the basses of the piano into a tragic monologue, this also is accented by the low register of the entire work: the romance is written for baritone or bassbaritone, and the sound of piano resembles the very low church bell in contra octave.

As mentioned, two other "Russian" romances were introduced later. The Bal on Ice to words by Nestor Kukolnik was written in the best traditions of Russian vocal lyrics, bringing to mind the famous Glinka's The Passing Song. It can be recognized as the undisputed masterpiece of Moniuszko's vocal lyrics. The short introduction is a bright accented passage, which is preceded by a virtuoso and at the same time transparent dance accompaniment in the genre of gallop ("Figure 1"). The hero's agitated tongue twister expresses his delight. Here Moniuszko appears as a keen 
connoisseur of vocal technique. The syncopated melody of the romance is written in a such way that the performer will involuntarily convey the excited speech of a young man who is waiting for an answer from his companion to his feelings for her. But the girl is cold and proud, so the romance ends at the climactic remark, in which she is compared to an ice mermaid, and himself - to the flame of lights in palaces. Only in 1972, the PWM published the couplets At That Time, found in the composer's archives. Nowaczyk discovered these lines in the genre of a vaudeville verse in the composer's archives, he suggests that the song was written before 1868, but it was not included in the "Russian" romances published by Bernard. On the title page there is a remark Wówczas - under this name it was published in 1972 by the PWM. Two short verses tell about a man persecuted by female power, dreaming to take everything "into his own hands" and represent a typical example of vaudeville style. Today, the couplets At That Time make us pay attention, first of all, to the intonation similarity with the vocal satires of Dargomyzhsky.

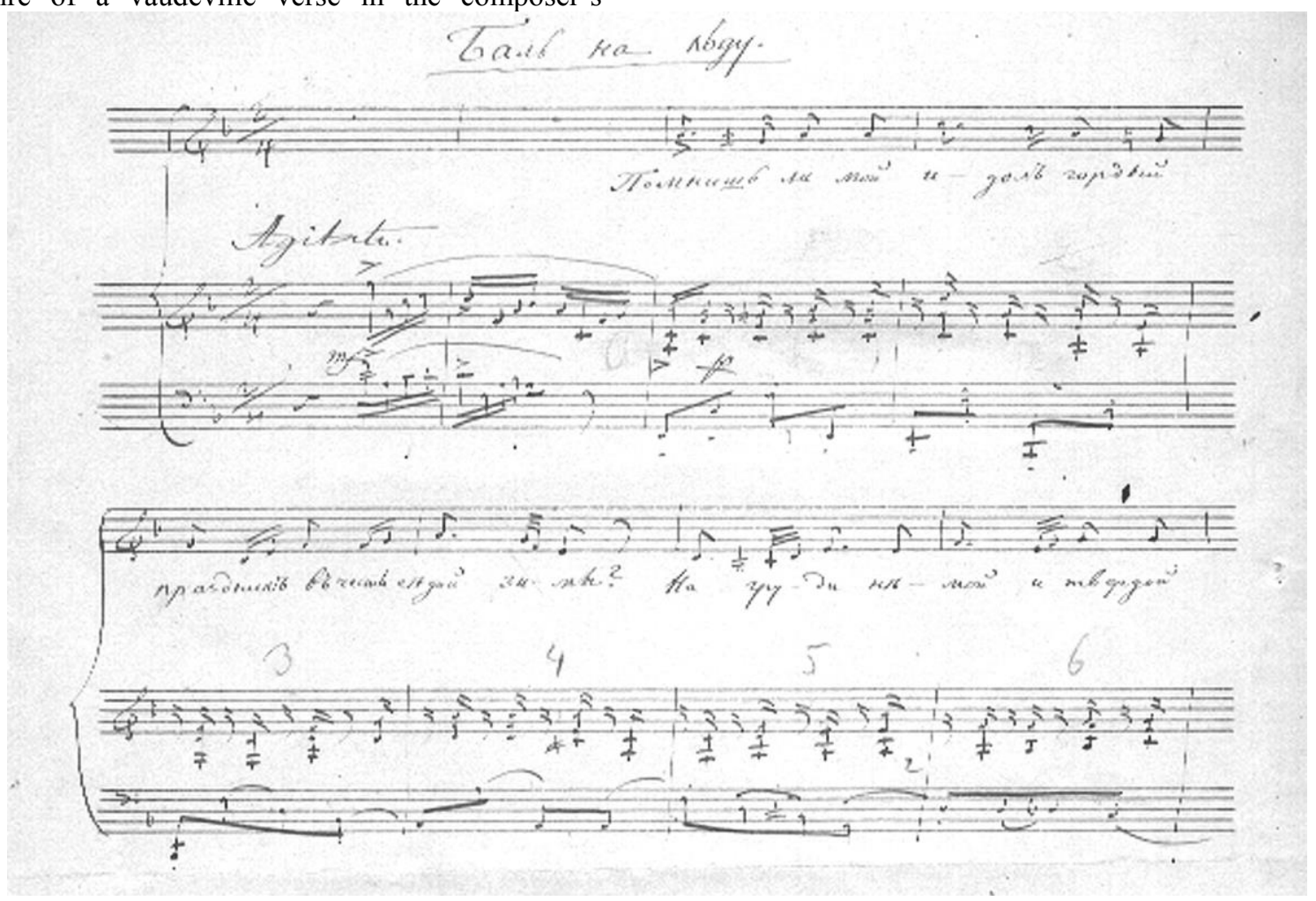

Figure 1 Fragment of the holograph by Moniuszko (The Bal on Ice), @ the Russian National Museum of Music.

\section{CONCLUSION}

Concluding the history of the creating and publishing of Moniuszko's romances to the words by Russian poets, it should be noted that the intrigue of their publications requires further clarification. In romances to verses by Russian poets, Moniuszko basically continues the Slavic, one might say, pre-Neman theme of his work: restrained melodies, often close to everyday ones, understandable and without any special frills motives. He uses subdominant turns which are characteristic for the harmony of Slavic composers, typical melodic formulas. The presented romances belong to the pearls of Moniuszko's vocal music. Nowadays, they are occasionally heard only in
Polish versions; the performers' task is to revive these forgotten pages of Moniuszko's oeuvre in their original version.

\section{AUTHORS' CONTRIBUTIONS}

This paper is independently completed by Olga Sobakina

\section{REFERENCES}

[1] Stanisław Moniuszko. Collection of articles edited by I. Belza, Moscow, GMI, 1952, p. 14.

[2] Stanisław Moniuszko. Collection of articles edited by I. Belza, Moscow, GMI, 1952, p. 64. 
[3] S. Moniuszko, The Selected Letters, Kraków, 1969, p. 75.

[4] Petersburg Weekly [Tygodnik Petersburski], № 72,1842 , p. 494.

[5] A. Walicki, Stanisław Moniuszko, Warszawa, 1873 , p. 59.

[6] Notes, extracts and correspondence F. B., in The Nothern Bee (Severnaya Pchela), № 73, 1849.

[7] The Vilnius Courier [Kurier Wileński], 1849.

[8] W. Rudziński, J. Prosnak, Moniuszko's Almanac [Almanach Moniuszkowski]. 18721952, The Reader [Czytelnik], 1952, p. 49.

[9] C. Cui, The Selected Articles, Leningrad, 1952, p. 206.

[10] Petersburg Weekly [Tygodnik Petersburski], № 32,1856 , p. 248.

[11] A. Serov, The Critical Articles, v. 1, St. Petersburg, 1892, pp. 481, 480. 